\title{
INDUCTION OF TEMPERATE CYANOPHAGES USING HEAVY METAL - COPPER
}

\author{
MAREI E.M. ${ }^{1}$, ELBAZ R.M. ${ }^{2 *}$ AND HAMMAD A.M.M. ${ }^{3}$ \\ 1 Virology Laboratory, Microbiology Department, Faculty of Agriculture, Ain Shams University- 11241, Egypt. \\ 2Botany and Microbiology Department, Faculty of Science, Helwan University, Ain Helwan- 11790, Egypt. \\ 3Microbiology Department, Faculty of Agriculture. Minia University, Minia- 61111, Egypt. \\ ${ }^{*}$ Corresponding Author: Email- d.reham@hotmail.com
}

Received: August 18, 2013; Accepted: September 15, 2013

\begin{abstract}
Presence of prophages in cells of three isolates of Anabaena sp. (Anabaena sp.1, sp.2 and sp.3), Anabaena cylindrica, Nostoc muscorum and Oscillatoria sp. was investigated. Copper sulfate at concentration of $3.1 \times 10^{-4} \mathrm{M}$ was successfully used for induction of temperate cyanophages. Among the cyanobacterial isolates tested Anabaena cylindrica was found to contain a prophage. A temperate phage was induced from Anabaena cylindrica by copper sulfate treatment and designated Ac-1. The induced phage isolate formed hazy circular plaques of $5 \mathrm{~mm}$ in diameter. The thermal inactivation point and longevity in vitro of the induced phage isolate (Ac-1) were found to be $70^{\circ} \mathrm{C}$ and 36 hrs., respectively. The induced cyanophage particles were examined by transmission electron microscopy. The phage particles were of head and tail type. The head diameter, tail length and tail width were found to be $50 \mathrm{~nm}, 116.6 \mathrm{~nm}$ and $8.3 \mathrm{~nm}$, respectively.

Ultrathin sections of infected $A$. cylindrica cells with temperate cyanophage and healthy ones were examined by electron microscopy. Marked changes in protoplasm and cell membrane, i.e. coagulation of protoplasm, formation of vesicles and vacuoles were observed in the infected cells as compared to the healthy ones. Phage particles were detected inside the infected $A$. cylindrica cells. Moreover, lysis of cell wall and release of the induced phage particles were also observed.
\end{abstract}

Keywords- Temperate cyanophage, Heavy metal, Cytopathic effect

Citation: Marei E.M., Elbaz R.M. and Hammad A.M.M. (2013) Induction of Temperate Cyanophages Using Heavy Metal - Copper. International Journal of Microbiology Research, ISSN: 0975-5276 \& E-ISSN: 0975-9174, Volume 5, Issue 5, pp.- 472-475.

Copyright: Copyright@2013 Marei E.M., et al. This is an open-access article distributed under the terms of the Creative Commons Attribution License, which permits unrestricted use, distribution and reproduction in any medium, provided the original author and source are credited.

\section{Introduction}

The lysogeny was found to be common in the marine environment, when a series of diverse marine environment were examined for prophage induction using mitomycin-C [1,2]. Moreover, Okhi [3] reported that mitomycin $\mathrm{C}$-stimulated prophage induction in cultured and natural samples of the filamentous cyanobacterium Trichodesmium sp. Using UV-radiation, up to $38 \%$ of the bacterial population were found to contain inducible prophage $[1,4]$.

The lysogenic Anacystis nidulans was treated with different concentrations of heavy metals-copper sulfate for induction of temperate phages. The temperate phage As-1 was induced by copper sulfate at concentrations from $3.1 \times 10^{-6}$ to $3.1 \times 10^{-4} \mathrm{M}$. Maximal phage induction occurred at $6^{\text {th }}$ hour after addition of copper sulfate at concentration of $3.1 \times 10^{-6} \mathrm{M}$. Titer of the induced phages was calculated as plaque forming units (pfu ) by a direct plating method [5].

Lysogenic cells of Anabeana sp.1 were treated with mitomycin C and examined by transmission electron microscopy. Thickness of the algal cell wall, coagulation of cytoplasm, appearance of vacuoles of different sizes and shapes, compact of the thylakoid and lysis of the cells were observed by Marei [2].
This work aims to induction of temperate cyanophages by using heavy metal-copper. In addition, cytopathic effect and alteration of cell structure due to induction of the temperate phages were also studied.

\section{Materials and Methods \\ Source of Cyanobacteria}

Anabaena sp.1, sp.2 and sp.3, Nostoc muscorum and Oscillatoria sp. were obtained from the Virology Lab., Microbiology Department, Faculty of Agriculture - Ain Shams University. Anabaena cylindrica was kindly provided by Plant Physiology and Phycology Lab., Botany and Microbiology Department, Faculty of Science - Helwan University.

\section{Induction of Temperate Cyanophage}

Erlenmeyer flasks each containing 95ml of Watanabe medium [6] were prepared. Five $\mathrm{ml}$ liquid culture $\left(10^{7} \mathrm{cfu} / \mathrm{ml}\right)$ of each cyanobacterial isolate were transferred separately into an individual flask. The flasks were incubated at $30^{\circ} \mathrm{C}$ under continuous illumination of fluorescence 5500-6500 lux for 10 days to reach exponential growth stage. Copper sulfate $\left(\mathrm{CuSO}_{4}\right)$ was then added to the cultures of each isolate at concentrations of $3.1 \times 10^{-3}-10^{-6} \mathrm{M}$. A culture with no 
copper sulfate was also involved as a control [5]. The induction of cyanophages was detected by clear lysis of the cyanobacterial culture after $24 \mathrm{hrs}$. from addition of copper sulfate. The lysed cultures were centrifuged at $3000 \mathrm{rpm}$ for $30 \mathrm{~min}$. The supernatant was obtained and maintained at $4^{\circ} \mathrm{C}$ over drops of chloroform.

\section{Detection and Isolation of Induced Cyanophages}

The Induced cyanophages were detected using the spot test technique. Isolation and purification of the induced temperate phages were carried out using single plaque isolation technique as described by Marei [2].

\section{Preparation of High Titer Cyanophage Suspension}

Liquid enrichment technique was used as described by Franche [7] to prepare high titer cyanophage lysate.

\section{Determination of Thermal Inactivation Point}

Eppendorf tubes each containing $1.5 \mathrm{ml}$ of high titer cyanophage suspension were prepared. Tubes were heated in water baths adjusted at $50,55,60 \ldots$...up to $90^{\circ} \mathrm{C}$ for $10 \mathrm{~min}$., then cooled under tap water. Ten $\mu l$ from each tube were spotted over double agar layer plates containing the appropriate indicator cyanobacteria. After incubation for $24-30 \mathrm{hrs}$. at $30^{\circ} \mathrm{C}$ under continuous illumination of fluorescence 5500-6500 lux, plates were inspected for lysis of cyanobacterial lawn at the sites where spots had been applied [2].

\section{Longevity in vitro}

Eppendorf tubes each containing $1.5 \mathrm{ml}$ of high titer cyanophage suspension were kept at room temperature. Samples were assayed qualitatively every $12 \mathrm{hrs}$. according to the method of Yoshida, et al [8].

\section{Host Range Assay}

Double agar layer plates were prepared. Each of the six cyanobacterial isolates was used as indictor host in individual plates. The surface of every plate was spotted with drops of each cyanophage isolate. After incubation for $24-30 \mathrm{hrs}$., at $30^{\circ} \mathrm{C}$ under continuous illumination of fluorescence 5500-6500 lux, plates were inspected for the lysed spots.

\section{Electron Microscopy of the Induced Cyanophage}

$5 \mathrm{ml}$ of the high titer phage suspension of the temperate cyanophage were centrifuged at $30,000 \mathrm{rpm}$ for $90 \mathrm{~min}$. at $4^{\circ} \mathrm{C}$ in a Bekman L7-35 ultracentrifuge. The pellet was gently resuspended in $0.5 \mathrm{ml}$ of $0.2 \mathrm{M}$ phosphate buffer $\mathrm{pH}$ 7.2. A drop of the resuspended pellet was placed on 200 mesh formvar-coated grid and allowed to settle for $1 \mathrm{~min}$. The excess liquid was removed with a filter paper wick. Grid was stained with $2 \%$ (w/v) phosphotungstic acid for 15 seconds. The grid was air dried and examined in JeolJem 1010 transmission electron microscope.

\section{Cytopathic Effect of Temperate Cyanophage on Cyanobacterial Cells}

The pellet of lysed cells which treated with $\mathrm{CuSO}_{4}$ were fixed and examined in Jeol-Jem 1010 transmission electron microscope using ultra thin section technique adopted by Luft [9].

\section{Results}

\section{Induction of Temperate Phage from Cyanobacteria}

Three isolates of Anabaena sp. (Anabaena sp.1, sp.2 and sp.3), Anabaena cylindrica, Nostoc muscorum and Oscillatoria sp. were treated with copper sulfate $\left(\mathrm{CuSO}_{4}\right)$ at concentrations of $3.1 \times 10^{-3}$ $10^{-6} \mathrm{M}$ for induction of temperate phages. Among the tested cyanobacteria Anabaena cylindrica was found to contain a prophage which successfully induced by copper sulfate at concentration of $3.1 \times 10^{-4} \mathrm{M}$. The induced phage was isolated, purified and designated Ac-1.

No prophages were detected in the other tested cyanobacteria when treated with the different prepared concentrations of $\mathrm{CuSO}_{4}$.

\section{Characteristics of the Induced Temperate Cyanophage (Ac-1) \\ Plaque Morphology}

As shown in [Fig-1], temperate phage (Ac-1) of Anabaena cylindrica formed hazy circular single plaques of $5 \mathrm{~mm}$ in diameter.

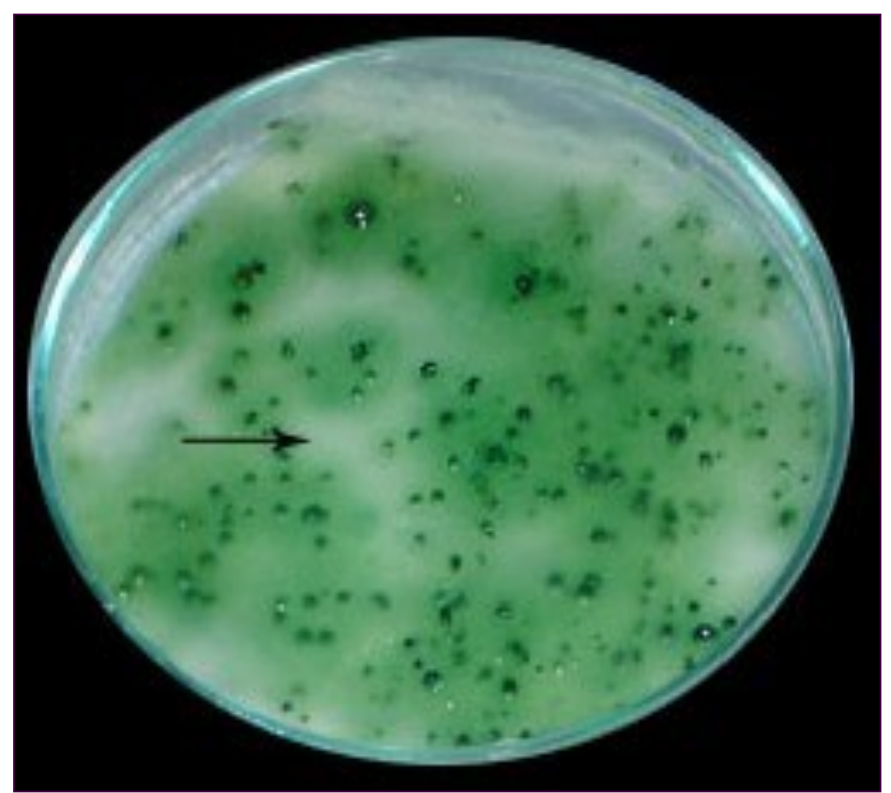

Fig. 1- Double layer agar plate containing bacterial lawn of $A$. cylindrica. Single plaques of Ac-1 temperate phage can be clearly seen.

\section{The Thermal Inactivation Point and Longevity in vitro}

The thermal inactivation point of the induced temperate phage (Ac1) and its longevity in vitro were found to be $70^{\circ} \mathrm{C}$ and $36 \mathrm{hrs}$., respectively.

\section{Host Range of the Induced Temperate Cyanophage}

The susceptibility of each of the tested six cyanobacterial isolates to the induced temperate cyanophage (Ac-1) was tested. As shown in Table (1) temperate cyanophage (Ac-1) was infectious to Anabaena cylindrica among the cyanobacterial isolates tested. The other cyanobacterial isolates (Anabaena sp.1, Anabaena sp.2, Anabaena sp.3, Nostoc muscorum and Oscillatoria sp.) were found to be resistant to the isolated cyanophage (Ac-1).

Table 1- Host range of the induced temperate cyanophage (Ac-1)

\begin{tabular}{lccccccc} 
Temperate & \multicolumn{7}{c}{ Cyanobacteria } \\
phage & $\begin{array}{c}\text { Anabaena } \\
\text { sp.1 }\end{array}$ & Anabaena & Anabaena & Anabaena & Nostoc & Oscillatoria \\
& - & - & sp.3 & cylindrica & muscorum & sp. \\
\hline $\begin{array}{l}\text { Ac-1 } \\
+=\text { Lysis; }\end{array}$ & $-=$ No lysis & & + & - & - \\
\hline
\end{tabular}

\section{Particle Size and Morphology}

The particles of the isolated temperate phage (Ac-1) were negatively stained with phosphotungstic acid and examined by transmission electron microscopy. As shown in [Fig-2] the induced temperate 
cyanophage (Ac-1) was of head and tail type. Data in [Table-2] indicate that dimensions of the phage particle were found to be 50 $\mathrm{nm}, 116.6 \mathrm{~nm}$ and $8.3 \mathrm{~nm}$ for the head diameter, tail length and tail width, respectively.

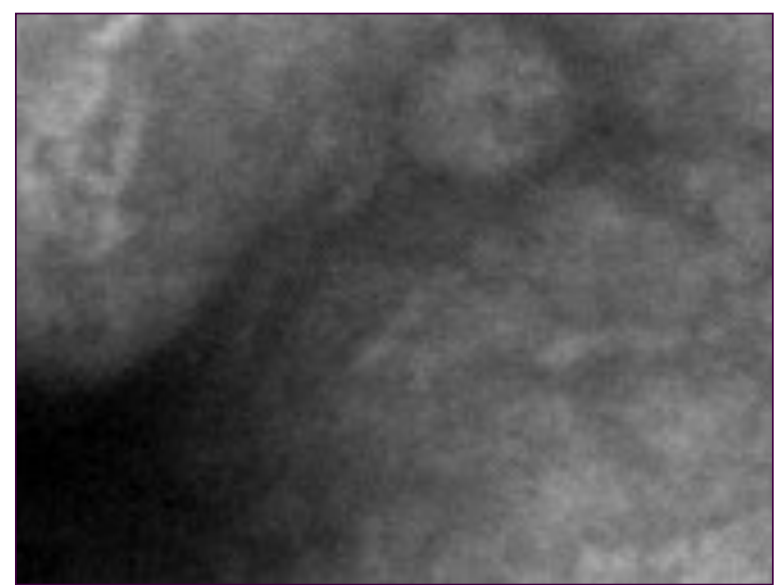

Fig. 2- Electron micrograph of temperate cyanophage (Ac-1). Magnification $=120,000 X$.

Table 2- Particle dimensions of the isolated temprate cyanophage (Ac-1)

\begin{tabular}{|ccc|}
\hline Head & Tail \\
Diameter & length & Width \\
$50 \mathrm{~nm}$ & $116.6 \mathrm{~nm}$ & $8.3 \mathrm{~nm}$ \\
\hline
\end{tabular}

\section{Cytopathic Effect of Temperate Cyanophage on A. cylindrica}

The electron micrograph of the healthy Anabaena cylindrica cells [Fig-3] showed the normal cell wall thickness, normal size of vesicles and normal photosynthetic lamella. Whereas, the infected cells of $A$. cylindrica with induced phage [Fig-4] and [Fig-5] showed highly thickening of cell wall, the cytoplasm appeared containing many vacuoles differed in their size and shape, cytoplasmic membrane exhibited irregular shape and the cell wall and cytoplasmic membrane were lysed.

The structures of viral particles are mainly of two types

1. Ellipsoid vesicle like bodies appearing singly or adhering to each other to form lamellae.

2. Elongated vesicle like bodies.

Adhesion was evident between vesicles of the same shape, as well as of different shapes with resultant formation of photosynthetic lamella. The infected cells also showed coagulation of both the cytoplasm and cytoplasmic membrane and enlarge of storage granules. The virus particles were appeared inside the infected cell in the late stage of infection.

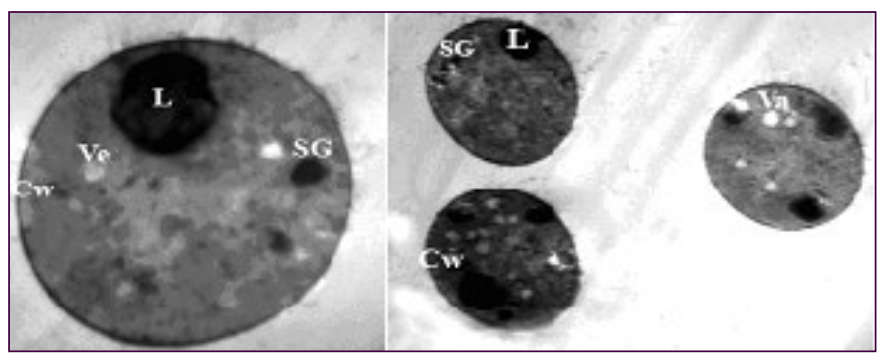

Fig. 3- Electron micrographs of $A$. cylindrica healthy cells.

$C w=$ Cell wall, Ve $=$ Vesicles, $S G=$ Storage granules, $L=$ Photosynthetic lamella.

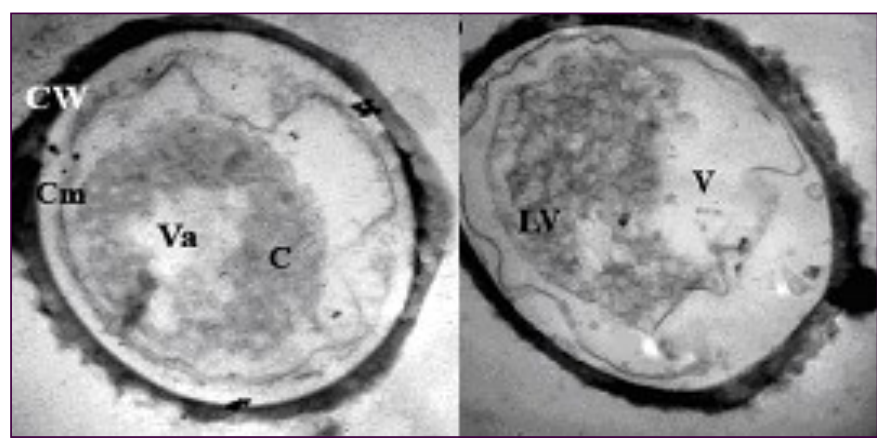

Fig. 4- Electron micrographs of $A$. cylindrica infected cells with temperate cyanophage (Ac-1) showing thickness of the cell wall, coagulation of cytoplasm and wavy cytoplasmic membrane.

$\mathrm{Cm}=$ Cytoplasmic membrane, $\mathrm{Va}=$ Vacuoles, $L v=$ Elongated vesicles, $V=$ Ellipsoid vesicles, $C=$ Coagulation of cytoplasm and cytoplasmic membrane.

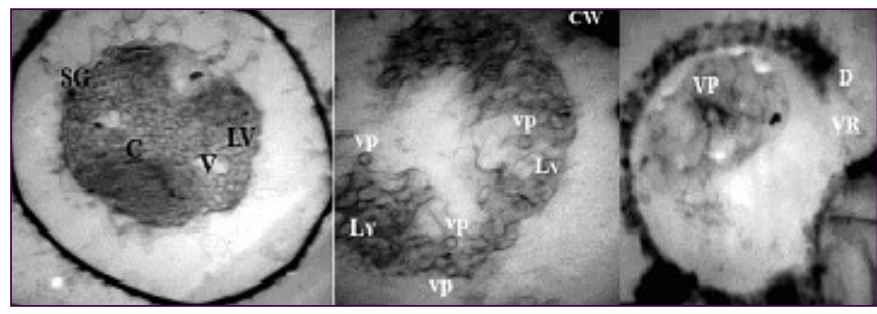

Fig. 5- Electron micrographs of $A$. cylindrica infected cells with temperate cyanophage (Ac-1) showing enlarge of storage granules, the virus particles and lysis of cell wall to emerge the virus particles. $S G=$ Storage granules, VP= Viral particles, VR= Virus release, $D=$ Lysis of cell wall, Lv= Elongated vesicles.

\section{Discussion}

In the present study a temperate phage was induced from Anabaena cylindrica using copper sulfate at concentration of $3.1 \times 10^{-4} \mathrm{M}$. The induced temperate cyanophage was designated Ac-1. Similar results were obtaind by Marei [2], who used mitomycin-C for induction of temperate cyanophage from Anabaena sp. Moreover, Lee, et al [5] found that AS-1 lysogenic phage can be induced by copper with a concentration ranged from $3.1 \times 10^{-6} \mathrm{M}$ to $3.1 \times 10^{-4} \mathrm{M}$.

The induced phage formed hazy circular plaques of $5 \mathrm{~mm}$ in diameter. The thermal inactivation point and longevity in vitro of the induced phage isolate were found to be $70^{\circ} \mathrm{C}$ and 36 hrs., respectively. Similarly, Marei [2], isolated a temperate cyanophage from lysogenic Anabaena sp. of $66^{\circ} \mathrm{C}$ thermal inactivation point and $48 \mathrm{hrs}$. longevity in vitro.

The induced cyanophage particles were examined by transmission electron microscopy. The phage particles were of head and tail type. The head diameter, tail length and tail width were found to be $50 \mathrm{~nm}, 116.6 \mathrm{~nm}$ and $8.3 \mathrm{~nm}$, respectively. Similar results were obtained by Marei [2].

Electron micrographs of $A$. cylindrica infected with the induced phage showed changes in cell structure compared with healthy ones. These changes include compact of photosynthetic lamella and vesicles, coagulation of cytoplasm, appearance of some virus particles and cell lysis. The attachment of the cyanophages to the photosynthetic vesicles was observed in this study. These results were relatively in agreement with those obtained by Marei [2] and Padan, et al [10]. The lamella consist of unit membrane vesicles often called thylakoid $[2,11]$. 
The above mentioned observations indicate that the infection with cyanophages occurs by injection of the phage DNA into the host cell. This contradict the earlier finding which postulate that the whole particle penetrates the cell and attach itself to the photosynthetic lamella [12]. The attachment of the cyanophages to the vesicles was observed in this study and also by Smith, et al [13]. The photosynthetic of the blue green algae appears to be composed of individual lamella which are not enclosed by a special membrane [14]. The number, shape and size as well as the intra cellular arrangement of these photosynthetic lamellae may differ among blue green algae species $[8,11]$. Moreover, the electron micrographs clearly show the adsorption and injection of the phage DNA into the host cell. Similar adsorption of cyanophage isolates to the cell wall of $A$. cylindrica was observed by Stanier \& van Niel [15].

In the present study the $A$. cylindrica cells were lysed by the induced phage isolate and release of the induced phages was observed. These results are in agreement with Marei [2] and Franche [7].

\section{Conclusion}

Generally, on the basis of the obtained results it can be concluded that, Anabaena cybindrica was found to contain a prophage. The temperate phage was induced by copper sulfate $\left(\mathrm{CuSO}_{4}\right)$ at concentrations of $3.1 \times 10^{-4} \mathrm{M}$ and designated Ac-1. The induced temperate phage was found to be of head and tail type. Ultrathin sections of infected $A$. cybindrica cells with temperate cyanophage indicated that marked changes in protoplasm and cell membrane, i.e. coagulation of protoplasm, formation of vesicles and vacuoles were observed in the infected cells as compared to the healthy ones. Phage particles were detected inside the infected $A$. cybindrica cells. Lyses of cell wall and release of the induced phage particles were also observed.

Conflict of Interest: None declared.

\section{References}

[1] Jiang S.C. and Paul J.H. (1996) Mar. Ecol. Prog. Ser., 142, $27-$ 28.

[2] Marei E.M. (2011) Studies on Virus Infecting Some Algae Isolated from Soil and Water, Ph.D. Thesis of Agricultural Microbiology, Agricultural Viruses, Faculty of Agriculture, Ain Shams University, Egypt.

[3] Okhi K. (1999) Bull. Inst. Oceanogr., 19, 287-291.

[4] Sode K., Oozeki M., Asakawa K., Burgess J.G. and Matsunaga T. (1994) J. Mar. Biotechnol., 1, 189-192.

[5] Lee L.H., Lui D., Platner P.J., Hsu S.F., Chu T.C., Gaynor J.J., Vega Q.C. and Lustigman B.K. (2006) BMC Microbiol., 6, 17.

[6] El-Nawawy A.S., Lotfi M., Fahmy M. (1958) Agricultural Research Review, 36, 308-320.

[7] Franche C. (1987) Arch. Microbiol., 148, 172-177.

[8] Yoshida T., Takashima Y., Tomaru Y., Shirai Y., Takao Y., Hiroishi S., Nagasaki K. (2006) Applied and Environmental Microbiology, 72(2), 1239-1247.

[9] Luft J.H. (1961) J. Biophys. Biochem. Cytol., 9, 409-414.

[10]Padan E., Shilo M. and Oppenheim A.B. (1972) Virology, 47, 525-526.

[11]Menke W. (1961) Z. Naturforsch., 16(B), 543-546.

[12]Smith K.M., Brown R.M.Jr., Walne P.L. and Goldstein D.A.
(1966) Virology, 30, 182-192.

[13]Smith K.M., Brown R.M.Jr., Goldstein D.A. and Walne P.L. (1966) Virology, 28, 580-591.

[14]Echlin P. and Morris I. (1965) Biological Reviews, 40, 143-184.

[15]Stanier R.Y. and van Niel C.B. (1962) Archiv für Mikrobiologie., 42, 17-35.

[16]Wildon D.C. and Mercer F.V. (1963) Aust. J. Biol. Sci., 16, 585596. 